\title{
Correction: Impact of oral corticosteroids on respiratory outcomes in acute preschool wheeze: a randomised clinical trial
}

Wallace A, Sinclair O, Shepherd M, et al. Impact of oral corticosteroids on respiratory outcomes in acute preschool wheeze: a randomised clinical trial. Arch Dis Child 2021:106:339-44. doi: 10.1136/archdischild-2020-318971.

The trial registration number was omitted during production of this article. It is anzctr.org.au: ACTRN12614000847617.

(c) Author(s) (or their employer(s)) 2021. No commercial re-use. See rights and permissions. Published by BMJ. Arch Dis Child 2021;106:e27. doi:10.1136/archdischild-2020-318971corr1

D Check for updates 